\title{
Kırsal Alanda Sosyal Sermayenin Yaşam Memnuniyeti Üzerine Etkisi
}

\author{
Şerafettin Keleş ${ }^{1}$ (D) Atilla Keskin² (D) Nur Ertek ${ }^{2}$ (D) \\ ${ }^{1}$ Erzincan Üniversitesi İktisadi ve İdari Bilimler Fakültesi, Erzincan ${ }^{2}$ Atatürk Üniversitesi Ziraat Fakültesi Tarım Ekonomisi Bölümü, \\ Errzurum \\ $\bowtie$ : akeskin.25@gmail.com
}

\section{ÖZET}

Başta ekonomi bilimi olmak üzere birçok bilim bireylerin ve toplumum mutlu yaşam sürmelerini hedeflemektedir. Birçok çalışmada yaşam memnuniyeti, demografik, genetik, psikolojik ve ekonomik değişkenlerle ölçülmeye çalışılmış ama sosyal sermaye pek dikkate alınmamıştır. Bu çalışmada, sosyal sermaye ile yaşam memnuniyeti arasındaki ilişki incelenmiştir. Tesadüfî Örnekleme Yöntemine göre yapılan hesaplamalar sonucunda anket sayısı 324 olarak belirlenmiştir. Erzurum kent merkezi dışındaki ilçe ve köylerde yapılan anketlerden elde edilen veriler kullanılmıştır. Yapısal Eşitlik Modelinin kullanıldığı çalışmada elde edilen bulgular yaşam memnuniyeti ile sosyal sermaye arasında pozitif yönlü bir etkileşimin olduğunu göstermektedir. İlişkisel Sosyal Sermaye $(0,65)$, Bilişsel Sosyal Sermaye $(0,62)$ ve Yapısal Sosyal Sermaye $(0,31)$ orta derecede pozitif yönde yaşam memnuniyetini etkilemektedir.

\section{The Effect of the Social Capital on the Life Satisfaction in Rural Areas}

\section{ABSTRACT}

Many fields of science, the economy being first, aim to ensure that the individuals and the society lead a happy and satisfactory life. Many studies attempted to measure the life satisfaction by the means of demographical, genetic, psychological and economic variables; however, the social capital has been largely overlooked in this manner. This study discusses the relationship between the social capital and the life satisfaction. In the study, in which the structural equation model was employed, the findings suggest that there is a positive relationship between the life satisfaction and the social capital. The associational social capital (0.65), Cognitive social capital (0.62) and the structural social capital (0.31) have an intermediate level effect on the life satisfaction in a positive direction.

\author{
Makale Tarihçesi \\ Geliş : 18.10.2018 \\ Kabul : 31.12.2018
}

\section{Anahtar Kelimeler \\ Yaşam Memnuniyeti, Sosyal Sermaye, \\ Kırsal Alan, \\ Türkiye}

\section{Araştırma Makalesi}

To cite: Keleş Ş, Keskin A, Ertek N 2018. Kırsal Alanda Sosyal Sermayenin Yaşam Memnuniyeti Üzerine Etkisi. KSÜ Tar Doğa Derg 21(Özel Sayı) : 123-132, DOI : 10.18016/ ksutarimdoga.vi.504999.

\section{Gỉiș}

Yaşam memnuniyeti, mutluluk veya iyi olma kavramları literatürde daha çok psikolojik açıdan ifade edilmektedir. Bu kavramlar yalnızca günlük hayatta kişilerarası "Nasılsın?" gibi sorguların cevaplarında değil, aynı zamanda yoğun bilimsel incelemelerin de odağı durumundadır. Her ne kadar "Nasılsın?" sorusu yeterince basit görünse de teorisyenler esenlik ve iyilik sorununu karmaşı ve tartışmalı bulmuşlardır. Nitekim entelektüel tarihin başlangıcından günümüze kadar iyi yaşamın ne olduğu ve iyi yaşamı neyin oluşturduğu konusunda önemli tartışmalar yaşanmaktadır. Açıkçası, bu tartışmaların çok önemli teorik ve pratik sonuçları bulunmaktadır. Mutluluğu tanımlama şekli

\section{Article History}

Received : 18.10.2018

Accepted : 31.12 .2018

\author{
Keywords \\ Life Satisfaction, \\ Social Capital, \\ Rural Area, \\ Turkey
}

\section{Research Article}

hükümetler, eğitim, ekonomi bilimi, tıp, insan sağlığı, ebeveynlik ve birçok uygulamaları etkilemektedir. Çünkü tüm bu çabalar, insanları daha iyi hale getirmek ve "daha iyi" olanın vizyonunu yakalamayı gerektirmektedir (Ryan ve Deci, 2001). Bilimsel çalışmalarda "mutluluk=happynees", yaşam memnuniyeti=life satisfaction" ve "iyi olma=wellbeing" terimleri birbirinin yerine kullanılmakta ve aynı durumu ifade etmekle birlikte farklı içerik ve tanımları yapılabilmektedir (Bjørnskov, 2003; Frey ve Stutzer, 2002).

Yaşam memnuniyeti, bir bütün olarak yaşamın kalitesi ve mutlu bir yaşam sürmenin derecesi olarak tanımlanmakla birlikte, sübjektif iyi oluşla ilgili bilişsel yargılardan oluşmaktadır (Diener, 2000). Bir 
başka tanımda yaşam memnuniyeti, bireyin beklentilerine ve kriterlerine uygun bir biçimde hayatını sürdürmesi ve hayatını olumlu değerlendirmesi olarak tanımlanmaktadır (Diener ve ark., 1985). Bireyin içinde yaşadığ toplumun kalitesi, toplumdaki konumu, yetenekleri, yaşanılan olayların etkisi, yaşamdan edinilen tecrübe, hissedilen duygular, hayata bakış açısı ve hayattan beklentiler gibi faktörlerin yaşam memnuniyeti ve memnuniyet alanı arasındaki ilişkiyi oluşturduğu önemle vurgulanmaktadır (Veenhoven, 1996).

Yaşam memnuniyeti ile ilgili bilimsel çalışmalar, öncelikle iki farklı felsefe etrafinda şekillenmekte ve mutluluğa ilişkin ampirik sorgular için nispeten birbirinden farklı, ancak örtüşen perspektifler ve paradigmaların oluşumuna neden olmaktadır. Bunlardan birincisi geniş olarak hedonizmden etiketlenmekte (Kahneman ve ark., 1999) ve mutluluğun zevk veya hazdan oluştuğu görüşünü yansıtmaktadır. İkinci görüş ise eudaimonizmi, yani üstün iyi olan mutluluğu, töresel mutluluğu ifade eder ki, bu da bilgiyle elde edilmektedir. Bilgiyle erişilen mutluluk, bilgenin mutluluğu, Sokrates'ten sonra hemen bütün Yunan düşünürlerince kabul edilmiş bir temadır. Buna göre, gelişimsel ve toplumsal süreçlerin mutlulukla ilgisi konusunda farklı yaklaşımlar önerilmektedir (Waterman, 1993).

Yaşam memnuniyeti üzerine yapılan araştırmaların önemli bir kısmı, dış etkenlerle mutluluk seviyesi arasındaki ilişkiye odaklanmıştır. Yaygın olarak yaş, ırk ve cinsiyet gibi temel demografik faktörlerin önemi vurgulanmakla birlikte, mutluluğun bir işe sahip olma, evlilik gibi diğer dış faktörlerle de önemli ilişkileri olduğu tespit edilmiştir. Sağlıklı olmak, dindar olmak ve eğitimin mutluluk ile küçük fakat önemli bir korelasyona sahip olduğu tespit edilmekle birlikte, yukarıdaki demografik faktörler ve dış etkenlerin yaşam memnuniyeti ile ilişkisi ve insanlarin mutlu olma veya olmama nedenleri tam olarak açıklanamamıştır (Leung ve ark., 2011). Ayrıca, genetik faktörler, iyimserlik, oto kontrol hissi, saygınlık ve dışa dönüklük gibi bireysel faktörlerin yaşam memnuniyeti ile ilişkili olduğu belirtilmektedir (Myers ve Diener 1995). Yukarıda açıklanmaya çalışılan demografik ve dış faktörlerle birlikte bireysel faktörlerin de eklenmesinden sonra bile, araştırmacılar halen yaşam memnuniyetine katkıda bulunan faktörleri tam olarak açıklayamamaktadır (Oishi ve ark., 2007).

Yaşam memnuniyeti ile ilgili çalışmalarda iç ve dış faktörlerin önemli rol oynadığı konusunda fikir birliği olmasina rağmen, mutluluğu önceden tahmin etmek ve ölçmek hala bir sorun olmaya devam etmektedir. Son yıllarda yapılan bilimsel araştırmalar, bu konuda sosyal sermayenin gözden kaçırılan hayati bir faktör veya kayıp halka olabileceğini ortaya koymaktadır (Leung ve ark., 2011). Mutlu bir bireyin özellikleri genç, sağlıklı, iyi eğitimli, iyi ücretli, dışa dönük, iyimser, endişesiz, dindar, evli, mütevazı, yüksek sayginlık, yüksek iş moraline ve yüksek iletişim becerisine sahip olmak şeklinde sıralanmaktadır (Hills ve Argyle, 2001; Diener ve ark., 2000; Frey ve Stutzer, 2002). Söz konusu bu bireysel özelliklerin önemli bir kısmı sosyal sermaye ile elde edilebildiğinden, hayat memnuniyetini açıklamada sosyal sermayenin gözden kaçırılmış önemli bir faktör olabileceği önemle belirtilmektedir (Scollon ve ark., 2004; Helliwell, 2006).

Lyubomirsky ve ark., (2005), bireylerin iyilik hallerinin korunmasına ve sürdürülebilirliğine yönelik olarak yaptıkları çalışmada sübjektif iyi olma durumu ile ilgili değişkenleri üç başlıkta gruplandırmışlardır. Birinci grup demografik ve sosyoekonomik değişkenlerden, yani; yaş, cinsiyet, eğitim düzeyi, ekonomik durum ve yaşanılan yer gibi yaşam koşullarından oluşmakta ve öznel iyi oluşu \%10 oranında etkilemektedir. İkinci grubu yaşamın etkinliklerini ifade eden hayatın gayesi ve bu gayeye ulaşma çabaları, dinin gereklerini yerine getirme, affedicilik, iyilik yapma ve yardım etme gibi ritüeller ve sosyal hayatın paylaşımları oluşturmaktadır. Sosyal sermaye olarak nitelendirilen bu bilişsel ve davranışsal etkinlikler \%40 oranında öznel iyi olmayı etkilemekte ve üçüncü grup olan genetik özellikler ve kişilik ise \%50 oranında mutluluğu etkilemektedir.

Sosyal sermaye, kişilerarası faaliyetlerle biriken ve bireyler ve topluluklar arasında güçlü bir sosyal ağ ve bağ oluşturmaya yardımcı olan bireysel kaynakları ifade etmektedir (Leung ve ark., 2011). Başka bir tamına göre sosyal sermaye, bireylerin ve grupların birbirleriyle olan bağlantılarından kazanç elde edebileceği fikridir (Paxton, 1999). Sosyal sermaye, bireyler ve kurumlar arasında işbirliğine dayalı eylemleri kolaylaştıran sivil toplumun normları, ağları ve karşılıklı güvendir (Coleman, 1988).

Sosyal sermaye kavramı türlerine göre yapısal, ilişkisel ve bilişsel olmak üzere üç ayrı kategoride incelenmektedir. Yapısal boyut, bireyler arasındaki bağlantıları ifade etmekte ve sosyal sermayenin kullanımında ve geliştirilmesinde gerekli olan diğer aktörlere, bireylere ve gruplara erişimi sağlamaktadır. Yapısal boyut, sosyal ağları, sosyal rolleri ve normları içermektedir (Krishna ve Shrader, 2000). Bilişsel sosyal sermaye, zihinsel süreçlerden oluşmakta, kültür ve inanışlardan beslenmekte, birlikteliği öne çıkaran normlar, değerler, tutumlar ve düşüncelerle varlık bulmaktadır. Dolayısıyla yapısal sosyal sermaye nesnel içeriklidir ve ağlara, sivil örgütlere, kurumlara ve kurallara işaret etmektedir. Bilişsel sosyal sermaye ise, soyut içeriklidir ve davranış normları, ortak değerler ve güven gibi öğeleri ifade etmektedir (Coleman, 1990). İlişkisel sosyal sermaye, bireyler arasında geliştirilen ilişkilerin yapısına atfen kullanılmakta ve etkileşim yoluyla insanların 
birbirleriyle geliştirmiş oldukları bireysel ilişki çeşitlerini ifade etmektedir (Carolis ve Saparito, 2006). Yapısal boyut insanların birbirleriyle ilişkili olup olmadığını incelerken, ilişkisel boyut bu ilişkinin içeriğine, kalitesine odaklanmaktadır. İlişkisel sermayenin en önemli özelliği kişilerarası güvene dayanmasıdir.

Yukarıda sıralan özellikler nedeniyle sosyal sermaye siyaset bilimi, sosyoloji, uygulamalı ekonomi ve sosyal psikoloji alanlarına önemli katkılar sunmaktadır (Perkins ve Long, 2002). Bu kapsamda yaşam memnuniyeti dünyanın dört bir yanındaki birçok disiplinde sosyal bilimcilerin ilgisini çeken önemli kişisel bir hedef konumundadır. Sosyal sermayenin yaşam memnuniyetini açıklamada gözden kaçırılan önemli bir faktör veya kayıp halka olabileceğini bir çok araştırmacı tarafından belirtilmesine rağmen, bu konuda yapılmış kapsamlı ve sistemli araştırmalar yeterli düzeyde değildir (Leung ve ark., 2011).

Bjørnskov (2003), yaşam memnuniyeti ile sosyal sermaye arasındaki ilişkiyi, sosyal sermayenin üç boyutuyla açıklamaya çalışmıştır. Coleman'ın (1988) teorisine uygun olarak sosyal güven, örgütsel faaliyetler ve sosyal normlar çalışmanın parametrelerini oluşturmaktadır. Bjørnskov'un Coleman tarafından önerilen üç sosyal sermayenin her bir biçimini temsil etmek için ampirik değişkenler kullanması çok bilgilendirici olsa da, araştırmasında sosyal sermayenin bazı önemli boyutlarını hesaba katmamıştır.

$\mathrm{Bu}$ çalışmanın amacı, yaşam memnuniyeti ile sosyal sermayenin farklı türleri arasındaki ilişkiyi incelemektir. Sosyal sermayenin kirsal alanda yaşam memnuniyeti üzerinde pozitif bir etkiye sahip olduğu, bu çalışmanın temel hipotezini oluşturmaktadır. Çalışma ile kırsal alanda yaşayan hane reislerinin yaşam memnuniyeti ve türlerine göre sosyal sermayenin yaşam memnuniyetine etkisi ampirik bir çalışmayla ortaya konulmaktadır. Bu yolla kırsal alanda birincil verilerin kullanılması ve yaşam memnuniyeti üzerine demografik ve sosyo-ekonomik özellikler, yapısal, ilişkisel ve bilişsel sosyal sermayenin etkilerinin birlikte incelendiği ilk çalışma olması nedeniyle literatüre önemli katkı sağlanacağı düşünülmektedir.

\section{MATERYAL ve METOT}

\section{Materyal}

Çalışmanın ana materyalini, Erzurum kent merkezi dışındaki ilçe ve köylerde yapılan anketlerden elde edilen veriler oluşturmaktadır. Bu veriler 2016 yılına ait yatay kesit verileridir. Çalışmada yazılım materyali olarak LISREL ve SPSS programları kullanılmıştır.
Metot

\section{Örnekleme}

Araştırma bölgesi Erzurum ili kırsal alanı olarak belirlenmiştir. Erzurum ili 20 ilçeye sahiptir. Kuzey ilçeleri Karadeniz Bölgesinin Doğu Karadeniz sınırları içinde kalmaktadır ve il topraklarının yaklaşık \% 30'luk bir payını oluşturmaktadır. Geriye kalan \% 70 gibi önemli bir pay Doğu Anadolu Bölgesi içinde yer almaktadır (Emiroğlu, 1972). Araştırmada anket yapılacak hane reisi sayısının belirlenmesinde $\% 5$ hata payı ve \%95 güvenirlik sinırları içerisinde çalışılmıştır. Tesadüfî Örnekleme Yöntemine göre yapılan hesaplamalar sonucunda anket sayısı 324 olarak belirlenmiş olup, hedef kitlenin benzer özellikler taşıyabileceği yani örnek hacminin homojen olduğu varsayılmıştır.

Tesadüfî Örnekleme Yöntemine göre anket sayısı aşağıdaki formülle belirlenmiştir (Çiçek ve Erkan, 1996).

$n=\frac{N \cdot S^{2} \cdot t^{2}}{(N-1) \cdot d^{2}+S^{2} \cdot t^{2}}$

$\mathrm{n}=$ Örnek hacmi

$\mathrm{N}=$ Örnekleme çerçevesine ait toplam birim sayısı

$\mathrm{X}=$ Ortalama (Geometrik)

$\mathrm{S}=$ Standart sapma

$\mathrm{d}=\mathrm{X}^{-*} 0.10$

$\mathrm{t}=$ Güven sinırı

\section{Veri Analizi}

Anket sorularının hazırlanması ve sahada uygulanması bir yıldan uzun bir süre almıştır. Anket formunun hazırlanmasinda Deiner ve ark., (1985) tarafından geliştirilen yaşam memnuniyeti ölçeği, Rasmussen ve ark., (2011) tarafindan Minnesota Üniversitesi'nde sosyal sermayenin ölçümüne yönelik geliştirilen anket formu ve Bjørnskov (2003) çalışmaları dikkate alınmıştır. Araştırmada kullanılan ankette katılımcıların demografik ve sosyoekonomik özelliklerine yönelik sorular ve sosyal sermaye ile yaşam memnuniyeti ölçeği soruları sorulmuştur. Demografik ve sosyo-ekonomik özellikler açık uçlu sorulardan elde edilmiş, sosyal sermaye ve yaşam memnuniyeti ölçeği ise likert ölçeği yöntemi ile kesinlikle katılmiyorum 1, katılmıyorum 2, orta derecede katılıyorum 3, katılıyorum 4, kesinlikle katılıyorum 5 puanla ölçeklendirilmiştir.

Verilerin analizinde Yapısal Eşitlik Modellemesi kullanılmıştır. Veriler analiz edilirken öncelikle gözlenen değişkenler belirlenmiş ve Path analizi yapılmıştır. Daha sonra gizil değişkenlerin veya varsayımsal yapıların gözlenen değişkenler tarafından nasıl tanımlandığını ve gözlenen değişkenlerin ölçüm özelliklerini (güvenilirlik ve geçerlilik) gösteren ölçüm modeli tanımlanmıştır (Jöreskog ve Sörbom, 1996). Bu model gözlenen ve gizil değişkenler arasındaki bağlantıların bir kümesini oluşturmaktadır. Ölçüm 
modelinin tanımlanmasından sonra yapısal eşitlik modeli oluşturulmuştur. Yapısal model gizil değişkenler arasında nedensel ilişkileri belirlemekte, nedensel etkileri tanımlamakta ve açıklanan ve açıklanmayan varyansı göstermektedir. Daha sonra yapısal modelin uygunluk ölçütleri hesaplanmış ve son olarak model tahmini yapılmıştır.

\section{Kuramsal Yapı}

\section{Yapısal Eşitlik Modeli}

Yapısal eşitlik modeli (YEM): açık (gözlenen, ölçülen) ve gizil (gözlenemeyen, ölçülemeyen) değişkenler arasındaki nedensel ve korelasyonel ilişkilerin bir arada olduğu modellerin test edilmesi için kullanılan bir istatistik yaklaşımıdır. Yöntemin temel özelliği, tamamen teoriye dayalı olmasıdır ve gizil değişkenler seti arasında bir nedensellik yapısının var olduğunu kabul etmesidir (Yılmaz 2004). Ayrıca, Yapısal Eşitlik Modellemesi veriyi istatistiksel olarak çözümlerken ölçüm hatalarını açıkça hesaba katmaktadır. Ölçüm hatalarının üstesinden gelmesinin yanı sira yapısal eşitlik modelleri araştırmacıların çok değişkenli karmaşı modeller geliştirilmesi, tahmin edilmesi ve test edilmesine de imkân sağlamakta ve verilen modeldeki değişkenlerin direkt ve dolaylı etkilerini de dikkate almaktadır. Temel olarak yapısal eşitlik analizinin amacı, önceden belirlenen bir ilişki örüntülerinin veri tarafından doğrulanıp doğrulanmadığını ortaya koymaktır (Bayram 2010).

Yapısal Eșitlik Modellerinin Matematiksel Yapısı: Bağımsız gizil değişkene ait gözlenen değişkenler için oluşturulan doğrusal eşitlikler aşağıdaki gibidir:

$\boldsymbol{x}=\boldsymbol{\Lambda}^{x} \cdot \boldsymbol{\xi}+\boldsymbol{\sigma}$

$\mathbf{x}$ : Gözlenen değişkenler matrisi,

$\Lambda^{x}$ : Bağımsız gizil değişkenlerin etkilediği, ölçülen bağımsız değişkenlere ait katsayılar matrisi,

$\xi$ : Bağımsız gizil değişken,

o: Bağıımsız gizil değişkene ait gözlenen değişkenlerin hata vektörüdür.

Bağımlı gizil değişkenlere ait gözlenen değişkenler için oluşturulan doğrusal eşitlikler aşağıdaki gibidir:

$\boldsymbol{y}=\boldsymbol{\Lambda}^{\boldsymbol{y}} . \boldsymbol{\eta}+\boldsymbol{\varepsilon}$

y: Bağımlı gizil değişkenlere ait gözlenen değişkenler vektörü,

$\Lambda^{y}$ : Bağımlı gizil değişkene ait gözlenen değişkenlerin katsayılar matrisi,

$\mathbf{n}$ : Bağımlı gizil değişken,

$\varepsilon$ : Bağımlı gizil değişkenlere ait gözlenen değişkenlerin hata vektörüdür.

Yapısal model için oluşturulan doğrusal eşitlikler aşağıdaki gibidir;

$\boldsymbol{\eta}=\boldsymbol{\Gamma} \cdot \boldsymbol{\xi}+\boldsymbol{B} \cdot \boldsymbol{\eta}+\boldsymbol{\zeta}$

$\Gamma$ : Bağımsız gizil değişkenlerin etkilediği bağımlı gizil değişkenlerin regresyon katsayıları matrisi,
$\boldsymbol{B}$ : Bağımsız gizil değişkenlerin etkilediği bağımlı gizil değişkenler arasındaki regresyon katsayıları matrisi,

そ: Bağımlı gizil değişkenlere ait, bağımsız gizil değişkenler tarafından etkilenmeyen hata matrisidir.

\section{Modelin Varsayımları:}

1. Gözlenen değişkenlerin çok değişkenli normal dağılıma sahip olduğu,

2. Gizil değişkenlerin çok değişkenli normal dağılıma sahip olduğu,

3. Gizil değişkenler arasında doğrusal ilişkilerin olduğu,

4. Gözlenen ve gizil değişkenler arasında doğrusal ilişkilerin olduğu,

5. Aykırı değerlerin var olduğu,

6. Hata terimlerinin korelasyonsuz olduğu,

7. Çoklu doğrusal bağlantı sorununun olmadığı,

8. Yeterli örneklem büyüklüğünün olduğu varsayılmaktadır.

Araştırmada kullanılan modelde bağımlı dışsal gizil değişken Yaşam Memnuniyeti Endeksi (LSI)'dir.

\section{Yaşam memnuniyeti endeksi kategorileri:}

- Bana göre bu köyde ideallerime yakın bir yaşantım vardir (L1)

- Bu köyde yaşam koşulları iyidir (L2)

- Köy yaşantımdan memnunun (L3)

- Köydeki yaşantım zamanla olumlu yönde değişti (L4)

- Tekrar dünyaya gelsem köyümü değiştirmezdim (L5)

Gözlenen değişkenler ise aşağıdaki gibidir.

Yaşam Memnuniyeti Ölçüm Modelinin içsel gizil bağı̆mlı değişsenleri;

$>$ Demografik Özellikler - Demographic Characteristics (DC)

> Sosyo-ekonomik özellikler - Socio-economic Characteristics (SEC)

$>$ Yapisal Sosyal Sermaye - Structural Social Capital (SSC)

> İlişkisel Sosyal Sermaye - Relational Social Capital (RSC)

> Bilişsel Sosyal Sermaye - Cognitive Social Capital (CSC)

- Demografik Özellikler (DC) gözlenen bağımsız değissken kategorileri

- Yaş (AGE)

- Eğitim (EDU)

- Aile Büyüklüğü (FS)

- Sosyo-Ekonomik Özellikler (SEC) gözlenen bağımsız değişsen kategorileri

- Etnik Yapı (ETN)

- İşletme Büyüklüğü (BS)

- Tarımsal Üretim Tecrübesi (APE)

- Yapısal Sosyal Sermaye (SSC) gözlenen bağımsız değissken kategorileri 
- Ailenizle olan ilişkilerimden memnunum (S1)

- Komşularınız ve arkadaşlarınızla olan ilişkilerimizden memnunum(S2)

- Geçen yıl, bir profesyonel tarım örgütü toplantısına katıldım (S3)

- Ilişkisel Sosyal Sermaye (SSC) gözlenen bağımsiz değisken kategorileri

- Aileme güvenirim (R1)

- Köylüye güvenirim (R2)

- Devlete güvenirim (R3)

- İnsanların geneli güvenilirdir (R4)

- Bilişsel Sosyal Sermaye (CSC) gözlenen bağımsIZ değişsken kategorileri

- Toprak mülkiyeti ile ilgili olarak köyde önemli farklılıklar bulunmamaktadır (C1)

- Etnik sorunlar köyde önemli farklılıklar oluşturmamaktadır (C2)

- Ülkemi meşgul eden konularla ilgilenirim (C3)

\section{ARAŞTIRMA BULGULARI ve TARTIŞMA}

\section{Demografik ve Sosyo-Ekonomik Bulgular}

Erzurum, Doğu Anadolu bölgesinin en kalabalık ve büyük şehirlerinden biridir. Farklı etnik köken ve mezhepten insanlar şehir merkezinde, ilçe ve köylerde birlikte yaşamaktadır. Ankete katılan hane reislerinin demografik ve sosyo-kültürel özellikleri aşağıda verilmektedir.

Sosyal ilişkilerde ve sosyal ağlara katılımda hane reislerinin yaşı önemli bir faktördür. Popülasyonda her yaş grubundan hane resisi bulunmaktadır. Çizelge 1'de hane reislerinin yaş dağılımı, eğitim düzeyi ve hane büyüklüğü verilmiştir.

Erzurum kırsal alanında örneklem içinde yer alan hane reislerinin \%33'ü 25-34 yaş grubunda yer almaktadır ve diğer yaş gruplarına göre daha yüksek bir orana sahiptir. 24 yaş altındaki hanereisi oranı $\% 6$ ile en düşük düzeydedir.

Sosyal sermaye araştırmalarında eğitime atfedilen önem, eğitimin sosyal ilişkilerde gösterdiği pozitif etki dolayısıyladır. Eğitim sosyal ağlara katılım, çevrenin imkânlarından faydalanma, örgütlenme, birlik ruhu ve sosyal kaynaşmada önemli bir faktör durumundadır.. Hane reislerinin \%43’ü ilkokul, \%29'u ortaokul, \%15’i lise, \%13’ü ise yüksekokul mezunudur.

\section{Ölçüm Modeli}

Ölçüm modeli oluşturulmadan önce ölçeklerin güvenirlilik testleri ve istatistiki analizleri yapılmıştır. En yaygın kullanılan yöntem olarak Cronbach's Alpha ${ }^{1}$ katsayısı, ortalama, standart sapma, standardize edilmiş faktör yük değerleri ve $t$

${ }^{1}$ Cronbach's Alpha Katsayısının değerlendirilmesinde kullanılan kriterler; $0.00 \leq \alpha<0.40$ ölçek güvenilir değil, $0.40 \leq \alpha<0.60$ ölçek değerleri hesaplanmıştır (Kalaycı, 2006). Çizelge 3'de model ve ölçeklere ilişkin güvenirlilik sonuçları ve istatistiki değerler verilmiştir.

Çizelge 1. Hane reislerinin yaş dağılımı, eğitim düzeyi ve hane büyüklüğü

\begin{tabular}{lrr}
\hline Yaş dağılımı & Frekans & \% \\
\hline 24 ve altı & 20 & 6.0 \\
$25-34$ & 107 & 33.0 \\
$35-44$ & 94 & 29.0 \\
$45-54$ & 67 & 21.0 \\
55 ve üzeri & 36 & 11.0 \\
\hline Toplam & 324 & 100.0 \\
\hline Ëğitim düzeyi & & \\
İlkokul & 140 & 43.0 \\
Ortaokul & 94 & 29.0 \\
Lise & 49 & 15.0 \\
Üniversite & 41 & 13.0 \\
\hline Toplam & 324 & 100.0 \\
\hline Hane & & \\
(kişi) & & \\
1-4 & & \\
5-8 & 75 & 23.0 \\
9-12 & 211 & 66.0 \\
12'den fazla & 28 & 8.0 \\
Toplam & 10 & 3.0 \\
\hline Kay̆g̈ü & 324 & 100.0 \\
\hline
\end{tabular}

Kaynak: Orijinal hesaplamalar.

Hane büyüklüğü bulguları araştırma bölgesinin genel yapısına uygun olarak doğurganlık oranının yüksek olduğunu ve çok çocuklu ailelerin çoğunluğu oluşturduğu göstermektedir. Ortalama hane büyüklüğü 6.35 olarak tespit edilmiştir. Erzurum kırsal alanında 1-4 arası çocuk sahibi hane oranı \%23’tür. 5-8 kişilik hane oranı \%66 iken, 9-12 kişilik hane oranı \%8, 12 kişiden daha fazla nüfusa sahip hane oranı ise \%3'tür.

Çizelge 2'de hane reislerinin etnik kökeni, arazi miktarı ve tarımsal tecrübeleri verilmektedir. Erzurum'da kırsal yerleşmeler tip, büyüklük ve etnik yapı açısından farklılık göstermektedir. Hane reislerinin \%36'sı Kürt kökenli iken, \%18'i Zaza \%6'sı ise Çerkez ve Gürcülerden oluşmaktadır.

İşletme büyüklüğü hane reislerinin sahip olduğu araziyle hesap edilmeye çalışılmıştır. Kırsal alanda hiç arazisi olmayanların oranı \%4'tür. Hane reisleri \%39 oranında 10 dekarın altında araziye sahipken, 150 dekar üzeri arazisi olan hane reisi oranı \%8'dir. Tarımsal alanda hane reislerinin çocukluklarından itibaren tarımla uğraştıkları ve yaşlarıyla orantılı olarak tarımsal tecrübeye sahip oldukları tespit edilmiştir. Hane reisleri çoğunlukla 10 yıl üzeri tarımsal üretimde fiilen çalışmaktadır.

düşük güvenilir, $0.60 \leq \alpha<0.80$ oldukça güvenilir, $0.80 \leq \alpha<1.00$ yüksek derecede güvenilir olarak değerlendirilmektedir. 
Çizelge 2. Hane reislerinin etnik kökeni, arazi miktarı ve tarımsal tecrübeleri

\begin{tabular}{lrr}
\hline Etnik Köken & Frekans & $\%$ \\
\hline Türk & 128.0 & 40.0 \\
Kürt & 116.0 & 36.0 \\
Zaza & 60.0 & 18.0 \\
Çerkez-Gürcü & 20.0 & 6.0 \\
\hline Toplam & 324.0 & 100.0 \\
\hline Arazi mikltarı (dekar) & & \\
Arazisi yok & 14.0 & 4.0 \\
1-10 & 125.0 & 39.0 \\
11-30 & 64.0 & 20.0 \\
31-50 & 37.0 & 11.0 \\
51-150 & 58.0 & 18.0 \\
150'den yukarı & 26.0 & 8.0 \\
\hline Toplam & 324.0 & 100.0 \\
\hline Tarımsal Tecrübe (yıl) & & \\
1-5 & 50.0 & 15.0 \\
6-10 & 44.0 & 14.0 \\
11-20 & 95.0 & 29.0 \\
21-30 & 94.0 & 29.0 \\
30 üzeri & 41.0 & 13.0 \\
\hline Toplam & 324.0 & 100.0 \\
\hline Kaynak: Orijinal hesaplamalar & & \\
& &
\end{tabular}

Modelde yer alan gizil değişkenlerden demografik özellikler ve sosyo-ekonomik özelliklerin faktör yük değerleri ve $t$ değerleri negatif çıkmıştır. Bu iki gizil değişken yaşam memnuniyeti üzerinde negatif bir etkiye sahipken diğer gizil değişkenlerin pozitif yönde ve anlamlı etkiye sahip olduğu tespit edilmiştir. Modelde yer alan değişkenlerin $t$ değerleri \pm 1.96 küçük olanlar \%5 önem seviyesinde istatistikî olarak önemsiz bulunmuştur.

Veri ile model arasındaki uyumu değerlendirmede kullanılan ölçüm kriteri olarak Ki-kare/serbestlik derecesi (X²/DF), $p$ değeri ve RMSEA (Root-meansquare error approximation) değerleri incelenmiştir. Model için için $\mathrm{X}^{2} / \mathrm{DF}$ değeri 2.72 olarak hesaplanmıştır (473.76/174). Bu değer kabul edilebilir değer olan beş ve beşten küçük değerler içerisinde yer almaktadır. Aynı şekilde RMSEA değeri yine kabul edilebilir değer olan 0.10 ve daha düşük değerler içerisindedir (0.074). Model $\mathrm{p}<0.0000$ değerini aldığ için \%5 önem seviyesinde istatistiksel olarak anlamlıdır.

Çizelge 3. Model ve ölçeklere ilişkin güvenirlilik sonuçları ve istatistiki bulgular

\begin{tabular}{|c|c|c|c|c|c|}
\hline Gizil ve gözlenen değişkenler & Ort. & Std. Sap. & $t$ değeri & $\begin{array}{l}\text { Faktör yük } \\
\text { Değerleri }\end{array}$ & $\begin{array}{c}\text { Cronbach's } \\
\text { Alpha değeri }\end{array}$ \\
\hline \multicolumn{6}{|l|}{ Yaşam Memnuniyeti İndeksi (LSI) } \\
\hline LS1 & 3.58 & 1.214 & 8.75 & 0.57 & 0.557 \\
\hline LS2 & 3.69 & 1.243 & 9.49 & 0.61 & 0.553 \\
\hline LS3 & 3.67 & 1.324 & 6.69 & 0.44 & 0.560 \\
\hline $\mathrm{LS} 4$ & 3.23 & 1.517 & 4.57 & 0.31 & 0.584 \\
\hline LS5 & 3.64 & 1.452 & 6.10 & 0.40 & 0.558 \\
\hline Demoğrafik Özellikler (DC) & & & -2.39 & -0.65 & \\
\hline Yaş (AGE) & 41.15 & 11.94 & 0.66 & -0.04 & 0.628 \\
\hline Eğitim (EDU) & 1.99 & 1.04 & 3.79 & 0.28 & 0.593 \\
\hline Aile Büyüklüğü (FS) & 6.35 & 3.22 & 4.97 & 0.52 & 0.594 \\
\hline Sosyo Ekonomik Özellikler (SEC) & & & -3.89 & -0.53 & \\
\hline Etnik Yapı (ETN) & 1.40 & 0.60 & 7.13 & 0.45 & 0.595 \\
\hline İşletme Büyüklüğü（BS） & 42.36 & 64.08 & 11.63 & 0.83 & 0.630 \\
\hline Tarımsal Üretim Tecrübe (APE) & 20.17 & 12.18 & 5.06 & 0.32 & 0.616 \\
\hline Yapisal Sosyal Sermaye (SSC) & & & 4.01 & 0.31 & \\
\hline S1 & 3.81 & 1.257 & 13.48 & 0.86 & 0.560 \\
\hline S2 & 3.52 & 1.325 & 11.59 & 0.72 & 0.566 \\
\hline S3 & 3.81 & 1.330 & 7.61 & 0.46 & 0.563 \\
\hline İlişkisel Sosyal Sermaye (RSC) & & & 6.88 & 0.65 & \\
\hline R1 & 3.44 & 1.420 & 8.95 & 0.54 & .551 \\
\hline R2 & 3.82 & 1.291 & 13.30 & 0.77 & .535 \\
\hline R3 & 3.52 & 1.313 & 7.84 & 0.48 & .565 \\
\hline $\mathrm{R} 4$ & 3.44 & 1.248 & 10.17 & 0.62 & .547 \\
\hline Bilișsel Sosyal Sermaye (CSC) & & & 4.21 & 0.62 & \\
\hline $\mathrm{C} 1$ & 3.42 & 1.224 & 6.81 & 0.49 & .573 \\
\hline $\mathrm{C} 2$ & 3.54 & 1.320 & 7.98 & 0.66 & .569 \\
\hline $\mathrm{C} 3$ & 3.70 & 1.400 & 0.07 & -0.01 & .573 \\
\hline
\end{tabular}

Kaynak: Orijinal hesaplamalar.

Chi-Square $=473.76 \quad \mathrm{df}=174 \mathrm{P}$-value $=0.00000 \quad \mathrm{RMSEA}=0.074$ 


\section{Yapisal Model}

Yapısal modelin temel amacı gizil değişkenler arasındaki ilişkiyi tanımlamak ve önerilen dönenceyi test etmektir (Kline, 2005). Ölçüm modeli ile tanımlanan yapısal modelin uyum istatistikleri ölçüm modeliyle aynıdır. Ölçüm modelinden farklı olarak gizil değişkenler arasındaki yapısal katsayılar incelenir (Bagozzi ve Yi, 1988; Sümer ve Bek, 2012).
Şekil 1'de yapısal eşitlik modeli ve standart değerleri verilmektedir. Buna göre yapısal eşitlik modeli için X/DF değeri 3.08 olarak hesaplanmiştır (567.03/184). $\mathrm{Bu}$ değer kabul edilebilir değer olan beş ve beşten küçük değerler içerisinde yer almaktadır. Aynı şekilde RMSEA değeri yine kabul edilebilir değer olan 0.10 ve daha düşük değerler içerisindedir (0.082). Model $\mathrm{p}<0.0000$ değerini aldığı için \%5 önem seviyesinde istatistiksel olarak anlamlıdır.

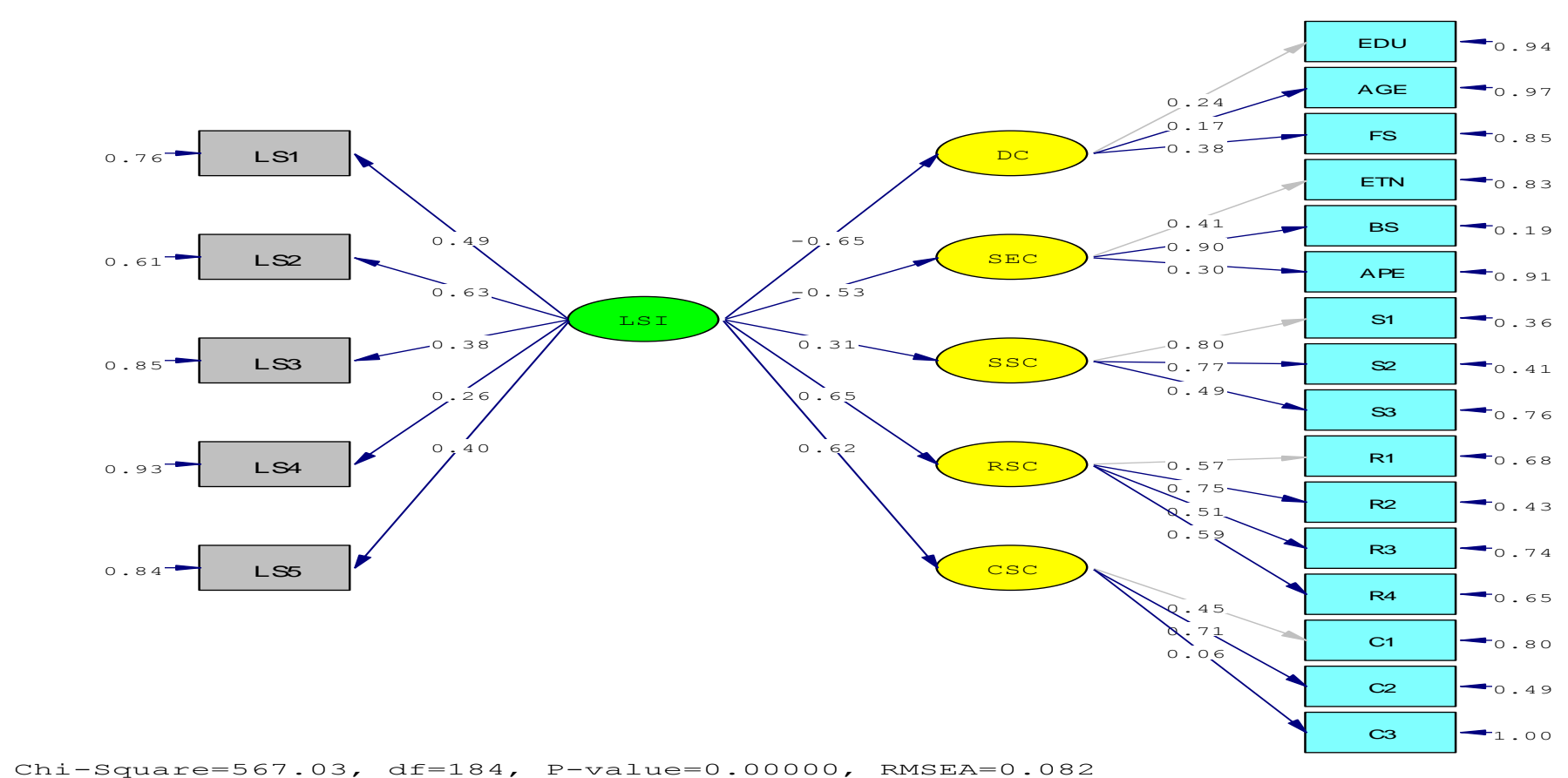

Şekil 1. Yaşam memnuniyeti yapısal eşitlik modeli ve standart değerleri

Standardize edilmemiş regresyon katsayıları hesaplanırken, her bir gizil değişkeni ölçmede kullanılan gösterge değişkenlerden biri tesadüfi olarak "bir" değeri alır. Bu değer dikkate alınarak diğer gösterge değişkenlerinin gösterge yükleri hesaplanır ve daha sonra bu değerler standart hale getirilir (Yeniçeri ve Erten, 2008). Standardize edilmiş katsayıların birin üzerinde olmaması gerekir. Standardize edilmiş çözümleme değerleri her bir gözlenen değişkenin kendi gizil değişkenini ne kadar iyi temsil ettiğini göstermesi açısından son derece önemlidir (Şimşek, 2007). Modelde standardize edilmiş katsayılar birin üzerinde değildir.

Modelin veri setine ne kadar uyduğunu değerlendirmede kullanılan kriterler Çizelge 4'de verilmiştir. Söz konusu değerlerin 1'e yakın olması veri ile model arasindaki uyumun mükemmel olduğunu göstermekte, sıfır ise uyumsuzluğu temsil etmektedir (Külter, 2011; Çelik ve Yılmaz, 2014). Bu araştırmada söz konusu kriterlere ilişkin değerler 1'e yakındır. $\mathrm{Bu}$ durum model ile veri setinin uygunluğunu göstermektedir.
Çizelge 4. Yapısal modelinin uyum indeksleri

\begin{tabular}{lcc}
\hline Uyum indeksleri & $\begin{array}{c}\text { Uyum indeksleri } \\
\text { sembolleri }\end{array}$ & $\begin{array}{c}\text { Model } \\
\text { değeri }\end{array}$ \\
\hline $\begin{array}{l}\text { Uyum iyiliği indeksi } \\
\begin{array}{l}\text { Düzeltilmiş uyum } \\
\text { iyiliği indeksi }\end{array}\end{array}$ & GFI & 0.85 \\
\hline $\begin{array}{l}\text { Normlaştırılmış uyum } \\
\text { indeksi }\end{array}$ & NFI & 0.81 \\
\hline Tucker-Lewis indeksi & NNFI & 0.72 \\
\hline Göreceli uyum indeksi & RFI & 0.76 \\
\hline $\begin{array}{l}\text { Karşılaştırmalı uyum } \\
\text { indeksi }\end{array}$ & CFI & 0.68 \\
\hline $\begin{array}{l}\text { Artırmalı uyum } \\
\text { indeksi }\end{array}$ & IFI & 0.79 \\
\hline
\end{tabular}

Kaynak: Orijinal hesaplamalar.

Çizelge 3'de yaşam memnuniyeti yapısal eşitlik modeli $t$ değerleri verilmiştir. Buna göre sırasıyla ilişkisel sosyal sermaye (6.88), bilişsel sosyal sermaye (4.21), yapisal sosyal sermaye (4.01), sosyo-ekonomik özellikler (-3.89) ve demografik özellikler (-2.39) \%5 önem seviyesinde istatistikî olarak önemli bulunmuştur. 


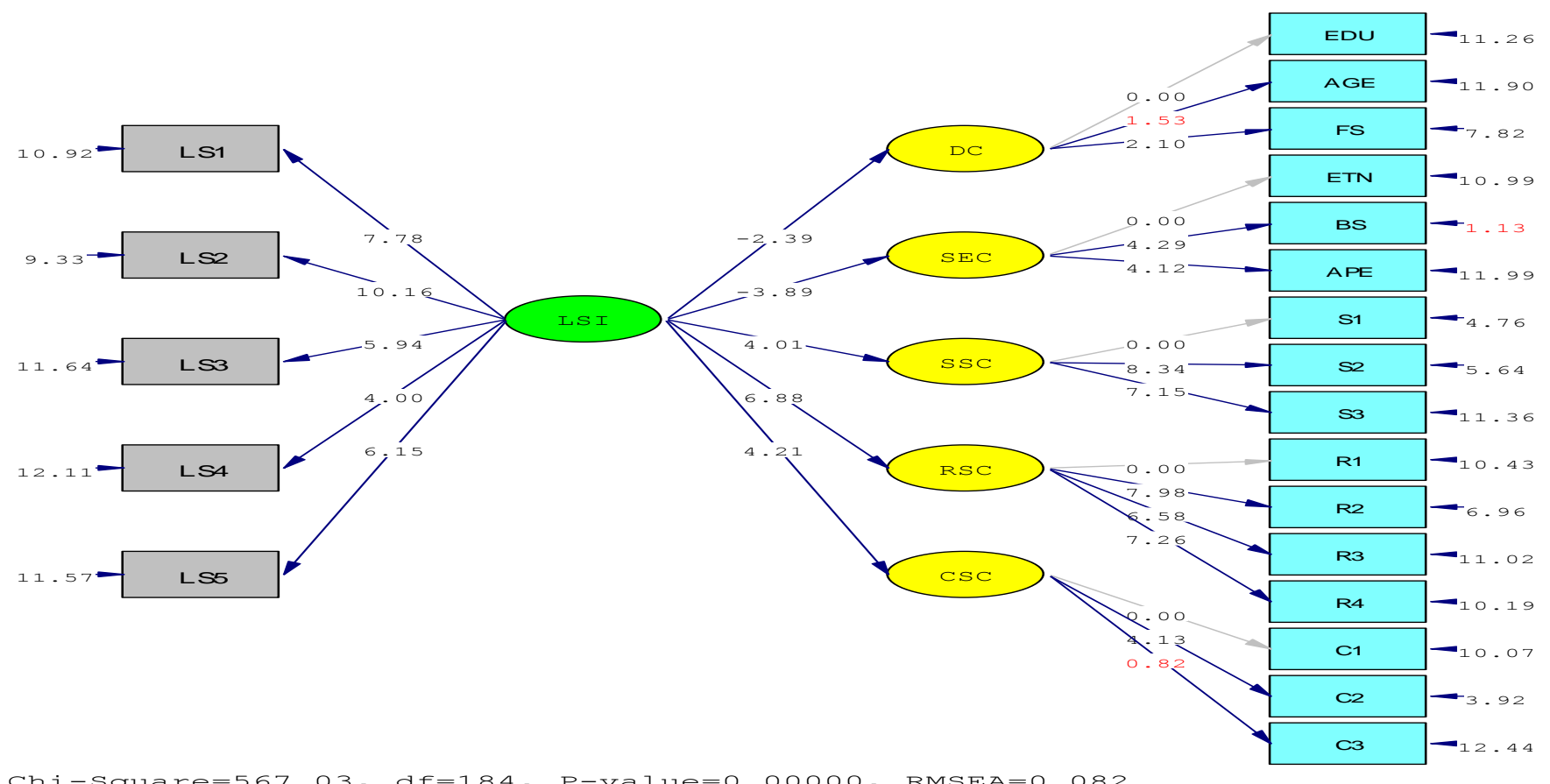

Şekil 2. Yaşam memnuniyeti yapısal eşitlik modeli $t$ değerleri

Model'de yaşam memnuniyeti ölçeği ile demografik özellikler (DC) ve sosyo-ekonomik özellikler (SEC) arasında negatif yönlü bir ilişki tespit edilmiştir. Bununla birlikte gerek yapisal sosyal sermaye (SSC), gerek ilişkisel sosyal sermaye (RSC) gerekse bilişsel sosyal sermaye (CSC) ile kırsal alanda yaşam memnuniyeti (LSI) arasında pozitif yönlü bir ilişki olduğu tespit edilmiştir.

Şekil 1'den anlaşılacağı gibi, ilişkisel sosyal sermaye, kırsal alanda yaşam memnuniyeti üzerinde pozitif yönlü orta düzeyde (0.65) bir etkiye sahiptir. Köylüye güvenirim (R2) ve "insanların geneli güvenilirdir (R4) en önemli (gözlenen değişken) faktörlerdir. Bu tespit kırsal alanda aileye, devlete ve köylüye duyulan yüksek güvenden kaynaklanmaktadır. Güven ilişki kurmakta temel faktördür ve güven ilişsilerin düzeyini ve içeriğini belirlemektedir. Kırsal alanda da hane başkanların mutlu hissetmelerine neden olan güven düzeyi önemli bir faktördür. Ancak güçlü aile bağlarının ve kültürel değerlerin varlığını koruduğu kırsal alanlarda, sosyal sermaye kaynağı olarak görülebilecek unsurlar yeterli ve etkili bir sivil toplum geleneği ile desteklenmemesi nedeniyle, sermaye değeri taşımak yerine toplumsal hareketlilik ve dayanışmayı kısıtlayan öğeler haline gelmiş durumdadır. Fukuyama (1995) Güney İtalya'da güçlü aile bağlarının eksikliği ve devletin kendileri için yatırım yapması gerektiğine inanılmasının sosyal sermaye eksikliğine neden olduğunu ve bu durumun girişimciliği başarısız kıldığını ifade etmektedir. Günümüzde birçok Afrika kentinde, hızlı kentleşmeyle birlikte eski siyasi yapılar ve aile bağları yerini akrabalık dışı güçlü gönüllü birliklere bırakmış ve böylece kalkınmanın önü açılmıştır. Çünkü geleneksel toplum yapısı ve aile bağları, büyük organizasyonları ve aile işletmelerini desteklememekte ve ekonomik faaliyet için verimli bir zemin sağlamamaktadır (Fukuyama, 1995).

Yine bilişsel sosyal sermaye sosyal yaşam memnuniyeti üzerinde pozitif yönlü (0.62) orta düzeyde etkiye sahiptir. "Etnik sorunlar köyde önemli farklılıklar oluşturmaz (C2) ve toprak mülkiyetiyle ilgili olarak köyde önemli farklılıklar yoktur (C1) en önemli faktörler olarak tespit edilmiştir. Yardımlaşma ve dayanışma, komşuluk ilişkileri ve bağlılık kırsal alanda güçlü ve yapıcı dostluklara dönüşmekte ve kırsal halkı birbirine kenetlemektedir. Kırsal alanda etnik farklılıklar olsa dahi bu durum etnik ayrımcılığa dönüşmemektedir. Farklı etnik kökenden gelen bireyler ve gruplar arasında güven, yardımlaşma ve karşılıklılık gözetilerek düzenlenmiş sosyal ağların, farklı etnik kökendeki bireylerin kaynaşma sürecine hizmet ettiğini ifade edilmektedir (Chan ve ark., 2006). Türkiye'de Adana ilinde yapılan bir çalışmada, sosyal sermayenin etnik kimliklerin birbirleri ile iletişim ve paylaşım olanaklarını artırdığını, karşılıklı etkileşim süreciyle kimlikler arasında ön yargıları azalttığını, güvenin artmasına ve kaynaşmaya katkı sağladığı tespit edilmiştir (Duman ve Alacahan, 2011).

Yapisal sosyal sermaye sosyal yaşam memnuniyeti üzerinde düşük düzeyde pozitif yönlü (0.31) etkiye sahiptir. Ailenizle olan ilişkinizden memnun musunuz? (S1) ve komşularınızla, arkadaşlarınızla olan ilişkinizden memnun musunuz? (S2) en önemli iki faktör olarak bulunmuştur. Bu durum kırsal alanda hane başkanlarının aileleriyle ve komşularıyla yapıcı 
ilişkiler kurma ve mutluluğu dostluklarda arama yönünde eğilimli olduklarını göstermektedir.

Modelde demografik özellikler (-0.65) ve sosyoekonomik yapı (-0.53) yaşam memnuniyeti ile negatif yönlü ve orta düzeyde bir etkiye sahiptir. Demografik özelliklerde aile büyüklüğü (FS) ve eğitim (EDU) en önemli faktörlerken, sosyo-ekonomik yapının gözlenen en önemli değişkenleri işletme büyüklüğü (BS) ve etnik köken (ETN) olarak belirlenmiştir. Yaşam mennuniyeti ile demografik ve sosyo-ekonomik yapı arasında tespit edilen negatif ilişki, kırsal alanda duyulan mutluluğun hedonik bir yapidan ziyade, eudaimonik bir karakter sergilemesinden kaynaklanmaktadır. Ayrıca, araştırma alanında eğitim durumunun arzu edilen düzeyde olmaması (Çizelge 1), hiç arazisi olmayan hane reislerinin olması ve hane reislerinin sahip olduğu arazi büyüklüklerinin önemli bir kısmının (39\%) 10 dekarın altında olması (Çizelge 2) önemli faktörlerdir. Demografik özellikler ve sosyo-ekonomik yapı yaşam memnuniyeti ile negatif yönlü bir ilişkiye sahip olmasına rağmen, özellikle gelir durumu ve eğitim gibi sosyo-ekonomik göstergeler bakımından iyi durumda olmayan Erzurum ilinde 2015 yılında yaşam memnuniyeti $65,7 \%$ olarak belirlenmiştir. $\mathrm{Bu}$ oran Türkiye ortalamasının (59,1\%) üzerindedir (TÜİK, 2016). Araştırma alanında yaşam memnuniyetinin Türkiye ortalamasının üzerinde olması, kırsal alanda güçlü bir sosyal sermaye düzeyi ile açıklanabilir. Bu durum kırsal alanda aileye, devlete ve köylüye duyulan yüksek güvenden kaynaklanmaktadır.

\section{SONUÇ}

Çalışmada elde edilen bulgular, sosyal sermaye ile yaşam memnuniyeti arasında güçlü bir ilişkinin varlığına işaret etmektedir. Araştırma sonuçlarına göre sosyal sermayenin her üç türü de yaşam memnuniyeti üzerine pozitif katkı sağlamaktadır. Bu durum kırsal alanda sosyal sermayenin önemini ve yaşam memnuniyeti üzerine etkisinin araştırmaya değer olduğunu göstermektedir.

Araştırma sonucuna göre güçlü aile bağlarının ve kültürel değerlerin varlığını koruduğu kırsal alanlarda, sosyal sermaye kaynağ 1 olarak görülebilecek unsurlar yeterli ve etkili bir sivil toplum geleneği ile desteklenmemesi nedeniyle, sermaye değeri taşımak yerine toplumsal hareketlilik ve dayanışmayı kısıtlayan öğeler haline gelmişlerdir. Politika yapıcıların eğitimli ve bilinçli bireylerin örgütlenme, özgürce fikirlerini ifade etme, sosyal ve siyasal süreçlere katılma ve işbirliği yapma özgürlüğüne sahip olabilmesi için gerekli koşulları sağlamaya yönelik politikalar geliştirmesi büyük önem arz etmektedir. Ayrıca yardımlaşma ve dayanışma, komşuluk ilişkileri ve bağlılık, kırsal alanda güçlü ve yapıcı dostluklara dönüşmekte ve kırsal halkı birbirine kenetlemektedir. Dolayısıyla kirsal alanda etnik farklılıklar olsa dahi bu durum kesinlikle etnik ayrımcılığa dönüşmemektedir. $\mathrm{Bu}$ durumda kırsal alanda etnik ayrımcılığın önündeki en önemli faktörün, güçlü aile bağları ve kültürel değerlerin korunmasina dayalı oluşan sosyal sermaye varlığı olduğu söylenebilir.

Son olarak, yaşam memnuniyeti ile demografik ve sosyo-ekonomik yapı arasında tespit edilen negatif ilişki, kırsal alanda duyulan mutluluğun hedonik bir yapıdan ziyade, eudaimonik bir karakter sergilediğine işaret etmektedir.

\section{KAYNAKLAR}

Bayram N 2010. Yapısal Eşitlik Modellemesine Giriş ve Amos Uygulamaları, Ezgi Print house, Bursa.

Bjørnskov C 2003. The happy few: Cross-country evidence on social capital and life satisfaction. Kyklos, 56 (1): 3-16.

Bagozzi PR ve Yi Y 1988. On the Evaluation of Structural Equation Models, Academy of Marketing Science Journal of the Academy of Marketing Science Spring, 16(1): 74-94.

Chan J, To HP, Chan E 2006. Reconsidering social cohesion: Developing a definition and Analytical Framework for Empirical Research. Social Indicators Research, 75(2): 273-302.

Coleman JS 1988. Social capital in the creation of human capital. American journal of sociology, 94: 95-120.

Coleman JS 1990. Foundations of social theory. Cambridge: Harvard University

Çelik HE ve Yılmaz V 2014. Lisrel 9.1 ile Yapısal Eşitlik Modellemesi. Arı Yayınları, İstanbul.

Çiçek A ve Erkan O 1996. Tarım Ekonomisinde Araştırma ve Örnekleme Yöntemleri. Gaziosmanpaşa Üniversitesi Ziraat Fakültesi Yayınları No: 12, Ders Notları Serisi No: 6, Tokat.

De Carolis DM ve Saparito P 2006. Social capital, cognition, and entrepreneurial opportunities: A theoretical framework. Entrepreneurship theory and practice, 30 (1): 41-56.

Diener E 2000. Subjective well-being: The science of happiness and a proposal for a national index. American psychologist, 55 (1): 34.

Diener ED, Emmons RA, Larsen RJ, Griffin S 1985. The satisfaction with life scale. Journal of personality assessment, 49 (1): 71-75.

Duman B ve Alacahan O 2011. Sosyal Sermaye/Güven Boyutunda Etniklik. Gaziantep University Journal of Social Sciences, 10( 1): 181-208.

Emiroğlu M 1972. A study regarding the area, number of parcels and parcel size of the rural settlements by geographical regions. Journal of Geographical Studies 3(4):109-138.

Frey BS ve Stutzer A 2002. The economics of happiness. World Economics, 3 (1): 1-17. 
Fukuyama, F 1995. Social Capital and the Global Economy Source. Foreign Affairs, 74 (5): 89-103.

Helliwell JF 2006. Well-Being, social capital and public policy: What's new?. The Economic Journal, 116(510): 34-45.

Hills P ve Argyle M 2001. Happiness, introversionextraversion and happy introverts. Personality and individual Differences, 30 (4): 595-608.

Jöreskog KG ve Sörbom D 1996. PRELIS 2 user's reference guide: A program for multivariate data screening and data summarization: A preprocessor for LISREL. Scientific Software International.

Kahneman D, Diener E, Schwarz N (Eds.). 1999. Wellbeing: Foundations of hedonic psychology. Russell Sage Foundation.

Kalaycı Ş 2006. SPSS Uygulamalı Çok Değişkenli İstatistik Teknikleri. Asil Yayın Dağıtım, Ankara.

Kline BR 2005. Principles and practice of structural equation modeling. the Guilford Press, 2nd ed., New York.

Krishna A ve Shrader E 2000. Cross Cultural Measures of Social Capital: A Tool and Results from India and Panama. Social Capital Initiative Working Paper No 21. Washington DC: World Bank.

Külter B 2011. Mağaza Özelliklerinin Perakendeci Marka Tercihi Üzerindeki Etkisi. Uluslararası Yönetim İktisat ve İşletme Dergisi, 7(14): 163-182.

Leung A, Kier C, Fung T, Fung L, Sproule R 2011. Searching for happiness: The importance of social capital. Journal of Happiness Studies, 12 (3): 443462.

Lyubomirsky S, Sheldon KM, Schkade D 2005. Pursuing happiness: The architecture of sustainable change. Review of general psychology, 9 (2): 111.

Myers DG ve Diener E 1995. Who is happy?. Psychological science, 6 (1): 10-19.

Oishi S, Diener E, Lucas RE 2007. The optimum level of well-being: Can people be too happy?. Perspectives on psychological science, 2 (4): 346-360.

Paxton P 1999. Is social capital declining in the United States? A multiple indicator assessment. American Journal of sociology, 105 (1): 88-127.

Perkins DD ve Long DA 2002. Neighborhood sense of community and social capital. In Psychological sense of community (pp. 291-318). Springer US.

Rasmussen C, Armstrong J, Chazdon S 2011. Bridging Brown County: Captivating social capital as a means to community change. Journal of leadership education, 10 (1): 63-82.

Ryan RM ve Deci EL 2001. On happiness and human potentials: A review of research on hedonic and eudaimonic well-being. Annual review of psychology, 52 (1): 141-166.

Scollon CN, Diener E, Oishi S, Biswas-Diener R 2004. Emotions across cultures and methods. Journal of cross-cultural psychology, 35 (3): 304-326.

Şimşek ÖF 2007. Yapısal Eşitlik Modellemesine Giriş, Temel Ilkeler ve Lisrel Uygulamaları, Ekinoks Yayınları, Ankara.

Sümer N, Bek Y 2012. Yapısal Eşitlik Modelleri ve LISREL Uygulamaları, Ondokuz Mayıs Üniversitesi Ziraat Fakültesi Fen Edebiyat Fakültesi, Samsun.

TÜIK 2016. İllerde yaşam endeksi gösterge değerleri, 2015. Türkiye İstatistik Kurumu, Ankara.

Veenhoven R 1996. Developments in satisfactionresearch. Social Indicators Research, 37 (1): 1-46.

Yeniçeri $\mathrm{T}$ ve Erten E 2008. Mağaza Sadakat Programlarının Algılanması, Güven, İlişkiyi Sürdürme İsteği ve Mağaza Sadakati Arasındaki İlişkilerin Yapısal Eşitlik Modeli İle İncelenmesi, Doğuş Üniversitesi Dergisi, 9 (2): 232-247.

Yılmaz V 2004. Lisrel ile Yapısal Eşitlik Modelleri Tüketici Şikayetlerine Uygulanması, Sosyal Bilimler Dergisi, 4(1): 77-90.

Waterman AS 1993. Two conceptions of happiness: Contrasts of personal expressiveness (eudaimonia) and hedonic enjoyment. Journal of personality and social psychology, 64 (4): 678-691. 